\title{
PENGARUH MEDIA PETA INTERAKTIF TERHADAP PEMAHAMAN DAN HASIL BELAJAR SISWA PADA MATA PELAJARAN IPS KELAS IV SD
}

\author{
Maya Kartika Sari *
}

\begin{abstract}
Teaching media has been applied and studied since long ago, but the significance of interactive map media in teaching social science at elementary school has not yet developed. This research is attempted to depict: the students' mastery on the places and sites, activeness and achievement. The research is conducted under two-cycle class action research on 30 students of four grade, SD Jetis, Bantul, Jogjakarta, at social science subject. The analysis brings about results that: (1) the students' mastery increases, from 4 students in preliminary reserach becomes 11 in the first cycle and 26 in the second cycle of the research, who master the teaching materials. (2) Students' activeness increases from 5 students in the prilimary research, to 10 in the first cycle and 28 in the second cycle, who are active in classes. (3) The students' achievement also increase from 6 students to 15 in the first cycle and 29 in the second cycle, who achieve better mark. The results suggest that interactive map is effective in teaching social science for the students of four grade.
\end{abstract}

Keywords : teaching social science, interactive map media.

\begin{abstract}
Abstrak
Media pembelajaran telah diterapkan dan dipelajari sejak lama, namun pentingnya media peta interaktif dalam pembelajaran ilmu sosial di Sekolah Dasar belum dikembangkan. Penelitian ini bertujuan untuk mengetahui: kemampuan siswa dalam menunjukkan letak dan lokasi, keaktifan dan hasil belajar. Penelitian ini dilakukan dua siklus dalam penelitian tindakan kelas pada 30 siswa kelas IV SD Jetis, Bantul, Jogjakarta, pada mata pelajaran IPS. Hasil analisis menunjukkan: (1) peningkatan pemahaman siswa dalam pembelajaran peta dari pra penelitian 4 siswa; kemudian pada siklus 1 sebanyak 11 siswa dan siklus 2 sebanyak 26 siswa. (2) adanya peningkatan keaktifan siswa dari pra penelitian sebanyak 5 siswa menjadi 10 siswa pada siklus 1 dan 28 siswa pada siklus 2. (3) adanya peningkatan hasil belajar siswa dari pra penelitian sebanyak 6 siswa meningkat menjadi 15 siswa pada siklus 1 dan 29 siswa pada siklus 2, yang menunjukkan hasil yang lebih baik. Hasil menunjukkan bahwa peta interaktif efektif dalam pembelajaran IPS untuk siswa kelas IV.
\end{abstract}

Kata kunci: Pembelajaran IPS, Media Peta Interaktif

* Maya Kartika Sari adalah dosen Program Studi PGSD IKIP PGRI Madiun 


\section{A. Pendahuluan}

Menurut Undang-Undang Republik Indonesia Nomor 20 Tahun 2003 tentang sistem pendidikan nasional "Pendidikan adalah usaha sadar dan terencana untuk mewujudkan suasana belajar dan proses pembelajaran agar peserta didik secara aktif mengembangkan potensi dirinya untuk memiliki kekuatan spiritual keagamaan, pengendalian diri, kepribadian, kecerdasan, akhlak mulia, serta keterampilan yangdiperlukan dirinya, masyarakat, bangsa, dan Negara."

Berdasarkan Undang-Undang No.20 Tahun 2003 tentang Sistem Pendidikan Nasional. Tujuan Pendidikan Nasional di rumuskan: Pendidikan Nasional berfungsi mengembangkan kemampuan dan membentuk watak serta peradaban Bangsa yang bermanfaat dalam rangka mencerdaskan kehidupan Bangsa. Bertujuan untuk berkembangnya potensi peserta didik agar menjadi manusia yang beriman dan bertakwa kepada Tuhan Yang Maha Esa, berakhlak mulia, sehat, berilmu, cakap, kreatif, mandiri dan menjadi warga negara yang demokratis serta bertanggung jawab.

Pembelajaran di Sekolah Dasar merupakan pendidikan dasar yang sangat penting bagi perkembangan siswa dan menjadi tolak ukur pendidikan selanjutnya. Dalam pembelajaran di sekolah dasar terdapat karakter siswa yang sangat beragam, oleh karena itulah diperlukan pendidik yang mampu menguasai pembelajaran dengan baik. Pengetahuan yang didapatkan siswa di sekolah dalam pembelajaran, salah satu nya mata pelajaran IPS. Dalam proses belajar mengajar terutama dalam pelajaran IPS terdapat kendala-kendala yang harus dihadapi oleh guru, salah satunya kebosanan dan kejenuhan siswa dalam menerima pembelajaran. Hal ini dikarenakan pembelajaran IPS yang terlalu banyak teori dan hafalan-hafalan, serta metode pembelajaran yang monoton serta kurangnya media pembelajaran yang mendukung proses pembelajaran.

Guru sebagai seorang pendidik yang merangkap sebagai fasilitator, mediator, motivator dan pembimbing harus mampu meningkatkan pembelajaran yang efeknya akan menimbulkan kecendrungan siswa menjadi lebih senang dan berminat dalam menjalani pembelajaran bersama dengan guru, Oleh karena itulah diperlukan metode sekaligus media pembelajaran yang menyenangkan yang mampu meningkatkan pemahaman dan hasil belajar siswa terutama dalam mata pelajaran IPS. Media pembelajaran yang dipilih dan digunakan oleh guru akan menentukan keberhasilan pencapaian pemahaman dan hasil belajar siswa secara optimal. Media yang digunakan harus dapat meningkatkan minat siswa dalam belajar sehingga akan memudahkan mereka dalam memahami materi yang disampaikan oleh guru.

SD Jetis Bantul merupakan sekolah dasar yang cukup berkualitas, hal ini dapat dilihat dari animo masyarakat yang cukup besar pada saat penerimaan siswa baru. Kualitas tenaga pendidik di sekolah ini termasuk bagus, karena mayoritas pendidik berijasah sarjana bahkan magister. Namun dalam pembelajaran terkadang sering terdapat hambatan-hambatan yang dihadapi oleh guru terutama dalam mata pelajaran IPS pada bab peta. Hal ini dikarenakan masih banyak nya guru yang hanya menggunakan metode ceramah dan mencatat saja, sehinga kurang interaksi dan komunikasi inteaktif dengan siswa. Selain itu media yang digunakan guru terkadang masih sangat monoton. Hal ini berakibat kejenuhan dan kurangnya minat siswa untuk mengikuti pelajaran. 
Berdasarkan permasalahan di atas, maka perlu adanya upaya untuk memperbaiki kualitas proses belajar mengajar terutama dalam pembelajaran IPS. Salah satunya dengan cara penggunaan media pembelajaran yang menarik, media yang dipilih adalah media yang sesuai dengan kemampuan berpikir siswa SD. Salah satu media pembelajaran yang dapat membuat pembelajaran lebih menyenangkan adalah media peta interaktif. Pembelajaran dengan menggunakan media peta interaktif tersebut akan mampu membawa kesegaran dan variasi bagi pengalaman belajar siswa. Selain itu dengan menggunakan media peta interaktif diharapkan mampu meningkatkan pemahaman siswa terhadap materi pelajaran yang berkaitan dengan peta Indonesia dan dunia, sehingga pemahaman siswa mengenai letak dan daerah akan semakin terasah, hal ini akan berimbas pada peningkatan hasil belajar.

\section{B. Kajian pustaka}

\section{Deskripsi Pembelajaran}

Pembelajaran merupakan suatu proses yang terdiri dari kombinasi dua aspek yaitu belajar tertuju kepada apa yang harus dilakukan oleh siswa, dan mengajar berorientasi kepada yang harus dilakukan oleh guru sebagai pemberi materi pelajaran. Kedua aspek ini akan berkolaborasi secara terpadu menjadi suatu kegiatan pada saat terjadi interaksi antara guru dengan siswa, serta antar siswa dengan siswa lain disaat pembelajaran sedang berlangsung.

Pembelajaran adalah inti dari proses pendidikan secara keseluruhan dengan guru sebagai pemegang utama. Pembelajaran merupakan suatu proses yang mengandung serangkaian perbuatan guru dan siswa atas dasar hubungan timbale balik yang berlangsung dalam situasi edukatif untuk mencapai tujuan tertentu (Usman, 2001 yang dikutip oleh Asep Jihad dan Abdul Haris, 2008:12). Dalam proses belajar baik guru maupun siswa bersama-sama menjadi pelaku terlaksananya tujuan pembelajaran. Tujuan pembelajaran ini akan mencapai hasil yang maksimal apabila pembelajaran berjalan secara efektif. Pembelajaran efektif adalah pembelajaran yang memudahkan siswa dalam mendapatkan informasi, pengetahuan dan wawasan serta hasil belajar yang diinginkan. Rancangan pembelajaran hendaknya memperhatikan hal-hal sebagai berikut :

a. Pembelajaran diselenggarakan dengan pengalaman nyata dan lingkungan otentik, karena hal ini diperlukan untuk memungkinkan seseorang berproses dalam belajar (belajar untuk memahami, belajar untuk berkarya, dan melakukan kegiatan nyata) secara maksimal.

b. Isi pembelajaran harus didesain agar relevan dengan karakteristik siswa karena pembelajaran difungsikan sebagai mekanisme adaptif dalam proses konstruktif, dekonstruktif dan rekonsiliasi pengetahuan, sikap dan kemampuan.

c. Menyediakan media dan sumber belajar yang dibutuhkan. Ketersediaan media dan sumber belajar yang memungkinkan siswa memperoleh pengalaman belajar secara konkrit, luas dan mendalam, adalah hal yang perlu diupayakan oleh guru yang proffessional dan peduli terhadap keberhasilan belajar peserta didik.

d. Penilaian hasil belajar terhadap siswa dilakukan secara formatif sebagai diagnosis untuk menyediakan pengalaman belajar secara berkesinambungan dan dalam bingkai belajar sepanjang hayat. (Asep Jihad dan Abdul Haris, 2008:13-14)

Interaksi belajar mengajar perlu adanya komunikasi yang jelas antara guru (pengajar) dengan siswa (peserta didik), sehingga terpadu dua kegiatan, yakni kegiatan mengajar (usaha guru) dengan kegiatan belajar (tugas siswa) yang berdaya 
guna dalam mencapai tujuan pembelajaran. Oleh karena itulah guru perlu mengembangkan pola komunikasi yang efektif dalam proses belajar mengajar.

Menurut Syaiful Bahri (2005:12-14), menyatakan bahwa dalam proses belajar mengajar, terdapat tiga pola komunikasi yang dapat digunakan untuk membangun interaksi antar guru dengan siswa yakni meliputi:

a. Komunikasi sebagai aksi komunikasi satu arah

Dalam komunikasi ini guru berperan sebagai pemberi aksi dan siswa sebagai penerima aksi. Guru aktif dan siswa pasif. Ceramah pada dasarnya adalah komunikasi satu arah atau komunikasi sebagai aksi. Komunikasi satu arah kurang banyak menghidupkan kegiatan siswa dalam belajar.

b. Komunikasi sebagai interaksi atau komunikasi dua arah

Dalam komunikasi ini guru dan siswa dapat berperan sama yakni pemberi aksi dan penerima aksi. Keduanya dapat saling memberi dan menerima. Komunikasi ini lebih baik dari yang pertama, sebab kegiatan guru dan siswa relatif sama.

c. Komunikasi sebagai tranaksi

Dalam komunikasi ini tidak hanya melibatkan interaksi dinamis antara guru dengan siswa yang satu dengan yang lainnya. Proses belajar mengajar dengan pola komunikasi mengarah kepada proses pengajaran yang mengembangkan kegiatan siswa secara optimal, sehingga menumbuhkan keaktivan belajar siswa. Strategi belajar digunakan dalam komunikasi ini adalah diskusi dan simulasi.

Berikut akan diperjelas mengenai komunikasi yang biasa dipakai dalam proses pembelajaran, yakni :

1). Guru

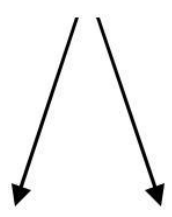

$M_{1} \quad M_{2}$
2). Guru

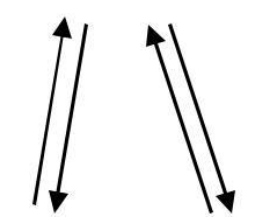

$\begin{array}{ll}M_{1} & M_{2}\end{array}$
3). Guru

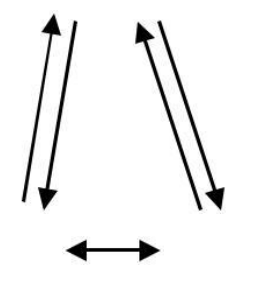

Keterangan:

1) Komunikasi satu arah sebagai aksi

2) Komunikasi dua arah sebagai interaksi

3) Komunikasi berbagai arah sebagai tranaksi

Ketiga pola komunikasi tersebut memberikan warna dan bentuk yang berbeda satu sama lain dalam pembelajaran.

Hasil belajar siswa dipengaruhi oleh jenis komunikasi yang digunakan guru pada saat mengajar. Pada pola pertama, komunikasi satu arah atau komunikasi sebagai aksi, menempatkan guru dalam kedudukan otoritas, dominan dan serba menentukan dalam proses belajar mengajar, sehingga bisa menumbuhkan sikap otoriter. Sebaliknya siswa cenderung menjadi objek belajar, pasif, dan tidak waspada bisa menimbulkan kesan belajar tidak terarah. Pada pola komunikasi ini siswa tidak mendapatkan kesempatan untuk aktif dalam pembelajaran, partisipasi siswa sangat kurang dan siswa kurang termotivasi dalam belajar.

Pola komunikasi dua arah yang melibatkan siswa dalam belajar mengajar, dinilai cukup baik diterapkan dalam pembelajaran. Hal ini dikarenakan siswa ditempatkan sebagai subjek dalam pembelajaran, sehingga siswa terlibat langsung 
dan dapat berperan aktif dalam pembelajaran. Namun kelemahan pola komunikasi ini adalah guru terlalu berpegang pada komunikasi dua arah, misalnya terus menerus tanya jawab atau tugas, dan sering pembahasan menyimpang dari bahan pengajaran, sehingga siswa akan menjadi bosan dan akan mencapai titik jenuh dalam mengajukan pertanyaan guru.

Pola komunikasi tranaksi menempatkan guru pada posisi sebagai pemimpin belajar atau pembimbing belajar atau fasilitator belajar. Sebaliknya siswa disamping sebagai obyek dapat pula sebagai subjek dalam pembelajaran. Pola komunikasi ini dinilai paling baik karena siswa akan sangat terdorong dalam proses belajar mengajar, siswa dapat berinteraksi dan berpartisipasi langsung dalam belajar, serta siswa dapat menjadi sumber dalam belajar maupun penerima informasi, sehingga terjadi pertukaran informasi dan pengetahuan antar siswa. Namun kelemahan dalam pola komunikasi ini akan terdapat beberapa anak yang cenderung menonjol di dalam kelas, oleh karenanya perlu adanya kontrol dan pengawasan guru dalam mengaktfkan belajar siswa, serta kombinasi dari ketiga kombinasi komunikasi sehingga pembelajaran semakin optimal. Untuk mendapatkan hasil yang optimal, sebaiknya guru menggunakan komunikasi dengan pola ketiga yakni komunikasi sebagai tranaksi, hal ini dikarenakan komunikasi ini tidak hanya siswa aktif dalam pembelajaran namun antar siswa dapat bertukar informasi dan wawsan dalam proses belajar mengajar.

\section{Deskripsi Ilmu Pengetahuan Sosial}

Tim IKIP Surabaya mengemukakan bahwa IPS merupakan bidang studi yang menghormati, mempelajari, mengolah, dan membahas hal-hal yang berhubungan dengan masalah-masalah human relationship hingga dapat dipahami dan diperoleh pemecahannya. Penyajiannya harus merupakan bentuk yang terpadu dari berbagai ilmu sosial yang telah terpilih, kemudian disederhanakan sesuai dengan kepentingan sekolah-sekolah.

Ilmu Pengetahuan Sosial IPS menurut Moeljono Cokrodikardjo (dalam Maya Kartika, 2012:2) didefinisikan sebagai perwujudan suatu pendekatan interdisipliner dari ilmu sosial yang merupakan integritas dari berbagai ilmu sosial yakni sosiologi, antropologi budaya, psikologi, sejarah, geografi, ekonomi, ilmu politik dan ekologi manusia yang diformulasikan untuk tujuan instruksional dengan materi dan tujuan yang disederhanakan agar mudah dipahami.

Menurut Udin S Winata (2007: 9) berpendapat bahwa IPS adalah salah satu bidang studi yang mempunyai tujuan untuk mengembangkan penalarannya disamping aspek nilai dan moral, banyak memuat materi sosial dan bersifat hafalan sehingga pengetahuan dan informasi yang diterima siswa sebatas produk hafalan. Hal ini menunjukkan bahwa pembelajaran IPS tersebut kurang mampu mengembangkan daya pikir siswa.

Tujuan dari pembelajaran IPS pada jenjang sekolah dasar sebagaimana dideskripsikan di atas, tampaknya dibutuhkan suatu pola pembelajaran yang mampu menjembatani tercapainya tujuan tersebut. Sehingga kemampuan dan keterampilan guru dalam memilih dan menggunakan berbagai model, metode, dan strategi pembelajaran senantiasa terus ditingkatkan, agar pembelajaran IPS di sekolah dasar benar-benar mampu mengkondisikan upaya pembekalan kemampuan dan keterampilan dasar bagi siswa untuk menjadi manusia dan warga negara yang baik. Karena pengkondisian iklim belajar merupakan aspek penting bagi tercapainya tujuan pendidikan. 
Pola pembelajaran IPS di sekolah dasar hendaknya lebih menekankan pada unsur pendidikan dan pembekalan pemahaman, nilai-moral, dan keterampilanketerampilan sosial pada siswa. Untuk itu, penekanan pembelajarannya bukan sebatas pada upaya mencekoki atau menjejali siswa dengan sejumlah konsep yang bersifat hapalan belaka, melainkan terletak pada upaya menjadikan siswa memiliki seperangkat pengetahuan, sikap, nilai, dan keterampilan agar mereka mampu menjadikan apa yang telah dipelajarinya sebagai bekal dalam memahami dan ikut serta dalam melakoni kehidupan masyarakat lingkungannya, serta sebagai bekal bagi dirinya untuk melanjutkan pendidikan ke jenjang yang lebih tinggi. Disinilah sebenarnya penekanan misi dari pembelajaran IPS di sekolah dasar.

Rancangan pembelajaran guru, hendaknya diarahkan dan di fokuskan sesuai dengan kondisi dan perkembangan potensi siswa agar pembelajaran yang dilakukannya benar-benar berguna dan bermanfaat bagi siswa. Dengan demikian pembelajaran Pembelajaran IPS semestinya diarahkan diarahkan pada upaya pengembangan iklim yang kondusif bagi siswa untuk belajar sekaligus melatih pengetahuan, sikap, nilai dan keterampilannya selama pembelajaran, disamping memungkinkan siswa untuk terlibat secara langsung dalam proses belajar mengajar.

Dalam kedudukannya sebagai pengembang dan pelaksana proses belajarmengajar, guru diharapkan mampu memilih dan merancang program pembelajarannya sebaik mungkin bagi pengembangan potensi diri siswanya. Pengembangan dan perancangan program pembelajaran ini harus di sesuaikan dengan tujuan dan esensi dari mata pelajaran yang akan di ajarkan pada siswanya. IPS merupakan mata pelajaran yang mempunyai fungsi dan peran yang sangat strategis dalam usaha pembentukan warga negara yang baik dan handal sesuai dengan tujuan pembangunan nasional.

Guru harus cermat dalam memilih model pembelajaran dan merancang program serta strategi pembelajaran, sehingga pembelajaran yang dilakukannya menjadi pembelajaran yang menarik, aktual, dan fungsional bagi siswa. Pemilihan model pembelajaran oleh guru mempunyai dampak yang sangat esensial bagi perolehan belajar siswa. Kondisi pembelajaran IPS di Indonesia dewasa ini lebih diwarnai oleh pendekatan yang menekankan pada model belajar konvensional yang lebih banyak diwarnai dengan ceramah, sehingga kurang mampu merangsang siswa untuk terlibat secara aktif dalam proses belajar-mengajar. Suasana belajar seperti ini semakin menjauhkan peran IPS dalam upaya mempersiapkan warga negara yang baik dan mampu bermasyarakat. Kondisi pembelajaran IPS dewasa ini khususnya pada jenjang sekolah dasar, menunjukkan indikasi bahwa pola pembelajaran yang dikembangkan oleh guru cenderung bersifat guru sentris sehingga siswa hanya menjadi objek pembelajaran.

Kondisi pembelajaran seperti di atas jelas tidak mendorong pengembangan potensi diri siswa dalam pembelajaran, sehingga hasil belajar yang dicapai oleh siswa juga tidak optimal, karena guru hanya mencekoki pikiran siswa dengan konsep-konsep materi pelajaran yang bersifat hapalan saja, kemudian dalam melakukan evaluasi juga hanya mengevaluasi materi yang diberikannya. Pembelajaran seperti itu, nampaknya tidak mampu menunjang dan mendorong siswa untuk mengaktualisasikan potensi dirinya secara optimal. Suasana belajar yang demikian mendorong lahirnya pola interaksi yang searah yaitu hanya dari guru ke siswa saja, sehingga akan mematikan kreativitas dan menghambat pengembangan potensi diri siswa. Model pembelajaran yang demikian, lebih 
cendrung berangkat dari asumsi dasar bahwa pembelajaran IPS hanya dimaksudkan untuk mentransfer pengetahuan atau konsep dari kepala guru ke kepala siswa. Akibatnya, mungkin guru telah merasa membelajarkan namun siswa belum belajar.

Konsekuensi logis dari pola pembelajaran yang demikian pada dasarnya sudah merupakan pengingkaran terhadap tujuan dan peran kritis yang diemban oleh IPS. Berdasarkan indikator-indikator tersebut, nampaknya kualitas proses pembelajaran IPS dewasa ini masih sangat rendah. Kondisi pembelajaran IPS sebagaimana yang di uraikan di atas, menyebabkan siswa kurang bergairah dalam mempelajari IPS, karena siswa hanya menghafal materi yang diberikan oleh guru, tanpa berusaha mencari dan mengembangkan pengetahuan dan pemahamannya pada hal-hal lain yang baru untuk menunjang dan memantapkan pemahaman mereka mengenai materi IPS.

Berdasarkan analisis empirik terhadap kondisi pembelajaran IPS di sekolah dasar dan kajian terhadap tujuan, esensi, dan peran kritis yang di emban oleh IPS, nampaknya persoalan tersebut memerlukan suatu alternatif pemecahan yang sangat mendesak untuk menjembatani persoalan-persoalan seputar proses pembelajaran IPS khususnya pada jenjang sekolah dasar. Artinya, diperlukan upaya-upaya yang terprogram untuk mengubah dan memperbaiki pola pembelajaran yang selama ini dikembangkan dan dilaksanakan oleh guru berdasarkan hasil kajian secara empiris dan pragmatis tentang realita yang terjadi di lapangan.

Peneliti mencoba mengembangankan pola pembelajaran interaktif yakni menggunakan media peta interaktif yang harapannya adalah siswa mampu memahami pembelajaran IPS terutama bab peta Indonesia dan dunia yang pada akhirnya mampu meningkatkan hasil belajar siswa.

\section{Deskripsi Media Peta Interaktif}

Peta adalah gambar permukaan bumi atau sebagian dari padanya. Secara langsung atau tidak langsung peta mengungkapkan sangat banyak informasi seperti lokasi suatu daerah, luasnya, bentuknya, penyebaran penduduknya, daratan, perairan, iklim, sumber ekonomi, serta hubungan satu dengan yang lain (Yudi Munadi, 2008: 96). Peta adalah gambaran permukaan bumi yang dibuat dengan menggunakan skala tertentu pada bidang datar. Bidang datar yang dimaksudkan berupa kertas (Sadiman, 2008: 5).

Peta adalah gambar seluruh atau sebagian dari permukaan bumi yang dilukiskan ke suatu bidang datar dengan perbandingan atau skala tertentu (Tantya, 2008: 3). Sedangkan menurut Muhammad Nursa'ban dan Rusmawan (2007: 17) menyatakan bahwa peta merupakan gambar yang menunjukkan letak suatu tempat. Pada peta terdapat pengukuran atau skala. Peta digunakan untuk menggambarkan letak atau daerah yang lebih luas seperti desa, provinsi dan negara.

Berdasarkan beberapa pendapat di atas dapat disimpulkan bahwa peta merupakan gambaran permukaan bumi yang menunjukkan letak suatu tempat yang dibuat pada bidang datar dengan menggunakan skala tertentu. Melalui peta orang dapat memvisualisasikan apa yang ada di sekitar tempat ia tinggal atau tempat yang pernah dikunjunginya. Oleh sebab itu, peta merupakan suatu alat visual yang berfungsi untuk memperluas pengetahuan dan pandangan terhadap bumi dimana seseorang menjalani hidupnya. Tanpa peta seseorang buta akan dunia, karena pengetahuannya terbatas hanya kepada apa yang ada di sekitar tempat tinggalnya dan tempat yang pernah di kunjunginya. 
Menurut Ginting, Fathur, Pinem (2004: 43) menyatakan bahwa jenis-jenis peta berdasarkan bentuknya, meliputi:

a) Peta timbul (Peta Relief)

Peta timbul adalah peta yang dibuat berdasarkan bentuk permukaan bumi yang sebenarnya. Pada peta timbul kita dapat melihat relief permukaan bumi karena pada peta tersebut bentuk- bentuk muka bumi yang dipetakan tampak dengan jelas.

b) Peta Datar ( Peta Biasa)

Peta datar adalah peta yang dibuat pada satu bidang datar, misalnya pada kertas. Pada peta datar, bentuk- bentuk permukaan bumi biasanya digambarkan dengan perbedaan warna yang tercantum pada legenda peta.

c) Peta Digital (Peta Terkomputerisasi)

Peta digital adalah peta yang datanya terdapat pada pita magnetik, sedangkan pengolahan dan penyajian datanya menggunakan komputer, misalnya peta yang digambarkan melalui layar televisi atau layar komputer.

Menurut Ginting, et. al (2004: 43) menyatakan bahwa fungsi peta yaitu :

a) Penunjuk jalan bagi orang-orang yang berpergian ke tempat-tempat yang belum pernah dikunjunginya.

b) Menunjukkan letak suatu tempat di permukaan bumi dalam hubungannya dengan tempat lain (letak relatif).

c) Memperlihatkan ukuran, karena dari peta dapat diukur jarak, luas dan arah sebenarnya di permukaan bumi.

d) Memperlihatkan bentuk seperti bentuk pulau, negara, benua, pola aliran sungai, dan sebagainya.

e) Membantu para peneliti sebelum melakukan survei untuk mengetahui kondisi daerah yang akan diteliti.

f) Alat untuk menjelaskan rencana-rencana yang diajukan, dan lain-lain.

Peta interaktif merupakan jenis peta digital, cara menggunakan media ini yakni menggunakan komputer atau laptop. Media peta interaktif berisi peta dunia dan peta Indonesia yang didesain sedemikian rupa sehingga tampilannya menjadi menarik dan menantang bagi siswa. Media peta iteraktif menuntut siswa untuk memahami peta, mampu menunjukkan letak daerah, mampu berinteraksi dengan guru yang akan berimbas pada meningkatnya hasil belajar siswa. Melalui media peta interatif ini akan memunculkan pembelajaran yang kreatif, menyenangkan dan kerjasama yang baik antar siswa.

\section{Metode Penelitian}

\section{Setting penelitian}

Penelitian dilakukan di SD Jetis Bantul, dengan subjek penelitian siswa kelas IV dengan jumlah siswa 30 siswa. Alasan pemilihan subjek tersebut dikarenakan hasil belajar pada mata pelajaran IPS terutama bab peta dunia dan Indonesia kurang memuaskan, hal ini disebabkan karena guru hanya menggunakan metode ceramah yang monoton dan tidak menggunakan media/alat peraga yang tepat sehingga siswa mengalami kesulitan dalam memahami materi atau teori yang disampaikan guru.

Penelitian ini dilakukan selama 2 bulan mulai bulan Januari 2013 sampai Maret 2013. Adapun kegiatan penelitian dimulai dari pengajuan proposal, perencanaan rancangan penelitian, pembuatan perangkat pembelajaran, pelaksanaan siklus I dan siklus II, pengumpulan data, analisa data, dan pembuatan laporan penelitian. 


\section{Prosedur Penelitan a. Rancangan Penelitian}

Penelitian ini menggunakan desain penelitian tindakan kelas (Classroom action research) yang berusaha mengkaji dan merefleksi secara mendalam beberapa aspek dalam kegiatan belajar mengajar yaitu mengetahui kemampuan siswa dalam memahami materi pelajaran IPS, mengetahui kemampuan siswa dalam menunjukkan letak lokasi atau daerah pada peta, mengaktifkan siswa dalam pembelajaran dan meningkatkan hasil belajar siswa.

Desain penelitian PTK Model Kurt Lewin tergambar sebagai berikut :

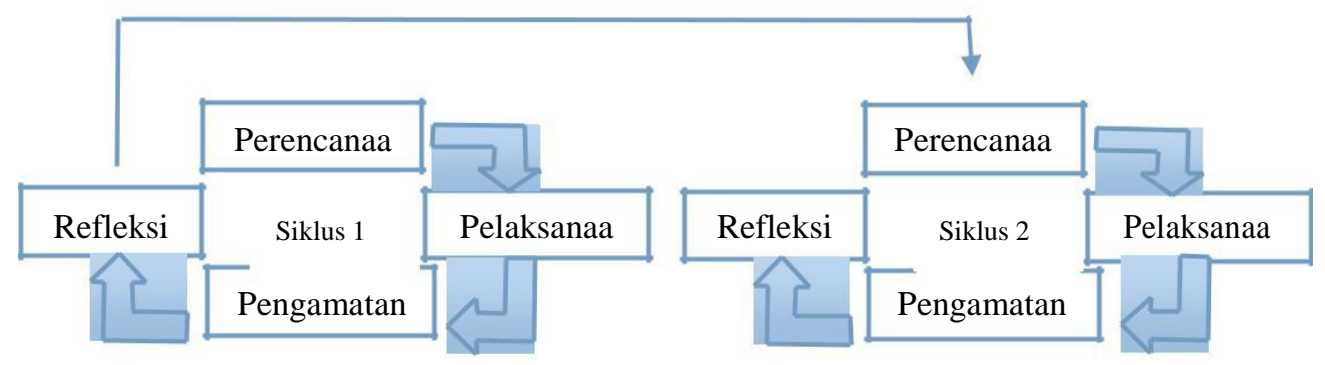

\section{b. Pelaksanaan penelitian}

Penelitian ini menggunakan penelitian tindakan kelas yang terdiri dari dua siklus, Tiap siklus terdiri dari empat tahap yakni perencanaan, tindakan, pengamatan dan refleksi. Dari tiap siklus diamati kualitas pembelajaran dengan menggunakan Media peta interaktif yakni menuntut siswa untuk memahami peta, mampu menunjukkan letak daerah, mampu berinteraksi dengan guru dan meningkatkan hasil belajar siswa.

\section{1) Siklus 1}

\section{a) Tahap perencanaan tindakan}

Pada tahap perencanaan ini, peneliti berkolaborasi dengan guru melakukan pra penelitian dengan mengamati terlebih dahulu permasalahan yang muncul dalam pembelajaran IPS, melihat keefektivan penggunaan metode dan media yang digunakan guru dalam proses pembelajaran, dan partisipasi siswa dalam pembelajaran. Setelah mengamati permasalahan yang muncul di lapangan, peneliti bekerjasama dengan guru merancang tindakan yang sebaiknya dilakukan agar pembelajaran pada materi memahami letak daerah pada peta menjadi lebih interaktif dan menarik. Maka dirancanglah langkah-langkah perencanaan sebagai berikut:

a. Menyusun rencana perbaikan pembelajaran mata pelajaran IPS melalui pembelajaran dengan menggunakan media peta interaktif

b. Merencanakan langkah-langkah kegiatan pembelajaran IPS melalui pembelajaran dengan menggunakan media peta interaktif

c. Meyusun pedoman pengamatan dan pedoman wawancara dalam pelaksanaan pembelajaran IPS melalui media peta interaktif

d. Merencanakan media peta interaktif yang akan digunakan dalam pembelajaran.

b) Tahap pelaksanaan tindakan

Tahap ini merupakan pelaksanaan ari rancangan yag telah disusun sebelumnya. Pelaksanaan tindakan berupa pelaksanaan pembelajaran IPS melalui media peta interaktif secara riil di kelas IV SD Jetis Bantul. Pelaksanaan penelitian 
peneliti berkolaborasi dengan guru dan teman sejawat dalam rangka pengumpulan data penelitian.

Pelaksanaan tindakan dilakukan dengan rangkaian siklus-siklus secara berulang. Siklus I dilakukan $2 \mathrm{x}$ jam pelajaran selama 60 menit, dan siklus II dilakukan 2 x jam pelajaran selama 60 menit, jika semua indikator tercapai maka siklus akan diakhiri.

\section{c) Tahap pengamatan}

Pada tahap pengamatan, peneliti berkolaborasi dengan guru mengamati secara intensif pelaksanaan pembelajran IPS melalui media peta interaktif secara riil di kelas IV SD Jetis Bantul. Hal-hal yang dilakukan oleh peneliti yakni mengamati dan mencatat semua gejala yang muncul baik yang mendukung maupun yang menghambat dalam pembelajaran IPS, mencatat atau merekam gejala yang muncul dalam pembelajaran pada lembar observasi berupa catatan check list, kemudian data diseleksi dan dianalisis menggunakan cara deskriptif kualitatif.

\section{d) Tahap refleksi}

Pada tahap refleksi, peneliti dan guru mengulas kembali pelaksanaan tindakan ada siklus I, apabila target yang telah ditetapkan belum tercapai dan pembelajaran dianggap kurang atau perlu adanya perbaikan, maka perlu adanya siklus II untuk memperbaiki pembelajaran pada siklus I. Harapannya pada siklus II pembelajaran menjadi lebih maksimal.

\section{2) Siklus 2}

Pada siklus II pembelajaran IPS dengan menggunakan media peta interaktif dilakukan sama tahapannya, yakni dari perencanaan, pelaksanaan tindakan, pengamatan dan refleksi. Pada siklus II gaya mengajar yang dilakukan guru dan peneliti pada siklus I diperbaiki agar pembelajaran menjadi lebih berkualitas. Selain itu guru dan peneliti perlu memperbaiki media/alat peraga dan pengendalian suasana kelas agar lebih kondusif dan meningkatkan rasa percaya diri siswa untuk berinteraksi dengan baik. Harapannya pada siklus II target yang diharapkan tercapai.

\section{Data dan cara pengumpulan data}

a. Sumber dan jenis data

Sumber data penelitian berasal dari seluruh anggota tim penelitian dan siswa kelas IV sebagai objek dari penelitian sebanyak 30 siswa. Jenis data pada penelitian ini adalah data kualitatif yakni berupa pengukuran kemampuan siswa memahami materi yang disajikan, mampu menunjukkan letak pada peta, Keaktifan siswa, kemampuan bekerjasama, dan mampu meningatkan hasil belajar. Sedangkan untuk standar angka pengukuran hasil dari data kualitatif menggunakan data deskripsi kuantitatif..

b. Teknik pengambilan data

Teknik pengambilan data dalam penelitian ini mengunakan lembar observasi (untuk mengetahui aktivitas pembelajaran IPS dengan menggunakan media peta interaktif), Catatan lapangan pada saat pembelajaran berlangsung, Wawancara yang dilakukan terhadap siswa dan guru, Dokumentasi berupa hasil belajar dengan menggunakan media peta interaktif juga dokumentasi aktivitas pembelajaran.

c. Teknik analisa data

Teknik analisa data yang digunakan adalah teknik deskriptif analitik yakni data kuantitatif menggunakan persentase, sedangkan data kualitatif untuk memperjelas data kuantitatif. 
d. Indikator Kinerja

Keberhasilan dalam penelitian ini diukur dengan adanya penigkatan kemampuan siswa dalam mamahami materi pelajaran IPS terutama bab peta dunia dan Indonesia target jumlah siswa yang mengalami peningkatan 25 siswa dari jumlah siswa 30 siswa.

\section{Hasil Penelitian Dan Pembahasan}

Penelitian ini bertujuan untuk melihat peningkatkan kemampuan siswa daam memahami materi yang disajikan, kemampuan siswa dalam menunjukkan letak pada peta, Keaktifan siswa, dan mampu meningkatkan hasil belajar.

Penelitian ini dilakukan dalam 2 siklus. Sebelum melakukan tindakan, peneliti berkolaborasi dengan guru melakukan pra penelitian. Hasil pra penelitian sebagai berikut.

Tabel 1 Hasil pra penelitian

\begin{tabular}{clcc}
\hline No & \multicolumn{1}{c}{ Aktivitas } & Jumlah siswa & Persentase \\
\hline 1 & Pemahaman materi & 4 & $13 \%$ \\
2 & Menunjuk letak lokasi pada peta & 2 & $6 \%$ \\
3 & Keaktifan siswa & 5 & $17 \%$ \\
4 & Hasil belajar & 6 & $20 \%$ \\
\hline
\end{tabular}

Berdasarkan hasil penelitian pada pra penelitian tersebut terlihat bahwa pembelajaran pada mata pelajaran IPS terutama pada bab peta dunia dan peta Indonesia masih kurang efektif. Hal ini dapat terlihat dari kurangnya pemahaman siswa dalam menjelaskan materi dan letak peta, hal ini dibuktikan sangat sedikitnya siswa yang memahami materi sebanyak $13 \%$. Selain itu kemampuan siswa dalam menunjukkan letak lokasi atau daerah di dalam peta hanya sebanyak $6 \%$ dan keaktifan belajar siswa dalam pembelajaran IPS sebanyak $17 \%$. Hal ini membuktikan bahwa masih banyak siswa yang pasif dalam pembelajaran dan belum memahami materi pelajaran dengan maksimal. Hasil pra observasi/pra penelitian ini juga membuktikan bahwa hasil belajar siswa masih sangat kurang hal ini terlihat hanya beberapa siswa yang mendapatkan hasil belajar yang baik. Setelah mengetahui hasil pra penelitian tersebut, peneliti berkolaborasi dengan guru melakukan pembelajaran menggunakan media peta interaktif pada siklus I. Hasil penelitian dan pembahasan dari siklus 1 adalah sebagai berikut:

Tabel 2 Hasil penelitian siklus 1

\begin{tabular}{llcc}
\hline No & \multicolumn{1}{c}{ Aktivitas } & Jumlah siswa & Persentase \\
\hline 1 & Pemahaman materi & 11 & $37 \%$ \\
2 & Menunjuk letak lokasi pada peta & 9 & $30 \%$ \\
3 & Keaktifan siswa & 10 & $33 \%$ \\
4 & Hasil belajar siswa & 15 & $50 \%$ \\
\hline
\end{tabular}

Berdasarkan hasil penelitian pembelajaran pada pelajaran IPS di siklus 1 diketahui bahwa pemahaman materi siswa pada bab peta mulai meningkat sebanyak 11 siswa (37\%), siswa telah mampu menunjukkan letak pada peta sebanyak 9 siswa (30\%) dan siswa sudah menunjukkan keaktivan dalam pembelajaran sebanyak 10 siswa (33\%). Hal ini menunjukkan peningkatan pembalajaran dibuktikan dengan 
lebih termotivasi siswa dengan menggunakan media peta interaktif. Hasil belajar siswa yang diharapkan juga mengalami peningkatan yang cukup baik, yakni sebanyak 15 siswa (50\%) mendapatkan nilai pembelajaran yang baik. Namun setelah dilakukan refleksi, ternyata pencapaian hasil belum mencapai indikator keberhasilan sehingga dilakukan kembali tahapan tindakan di siklus 2, harapannya di siklus 2 terdapat perbaikan pembelajaran.

Pembelajaran pada pelajaran IPS di siklus 2 dengan media yang sama yakni media peta interaktif namun gaya mengajar lebih ditingkatkan kualitasnya, Dari hasil penelitian yang dilakukan pada siklus II diketahui hasil penelitian pada tabel 3 berikut

Tabel 3 Hasil penelitian siklus 2

\begin{tabular}{llcc}
\hline No & Aktivitas & Jumlah siswa & Persentase \\
\hline 1 & Pemahaman materi & 26 & $87 \%$ \\
2 & Menunjuk letak & 29 & $97 \%$ \\
3 & Keaktifan siswa & 28 & $93 \%$ \\
4 & Hasil belajar siswa & 29 & $97 \%$ \\
\hline
\end{tabular}

Berdasarkan data diatas terlihat bahwa terdapat peningkatan pembelajaran siswa pada pelajaran IPS dengan menggunakan media peta interaktif. Hal ini dibuktikan dengan adanya peningkatan pemahaman materi siswa pada bab peta sebanyak 26 siswa (87\%), Kemampuan siswa dalam menunjukkan letak pada peta sebanyak 29 siswa (97\%) dan Siswa telah menunjukkan keaktivan dalam pembelajaran sebanyak 28 siswa (93\%). Hal ini menunjukkan telah terjadi peningkatan kualitas pembelajaran pada mata pelajaran IPS terutama pada bab peta dunia dan peta Indonesia, terbukti dengan hasil belajar siswa yang meningkat cukup signifikan yakni 29 siswa (97\%) yang mendapatkan nilai yang baik dalam pembelajaran. Pada siklus 2 telah mencapai target atau indikator keberhasilan kinerja, sehingga penelitian ini berakhir di siklus 2 .

Untuk memperjelas peningkatan pembelajaran IPS dengan menggunakan media peta interaktif terlihat pada grafik berikut.

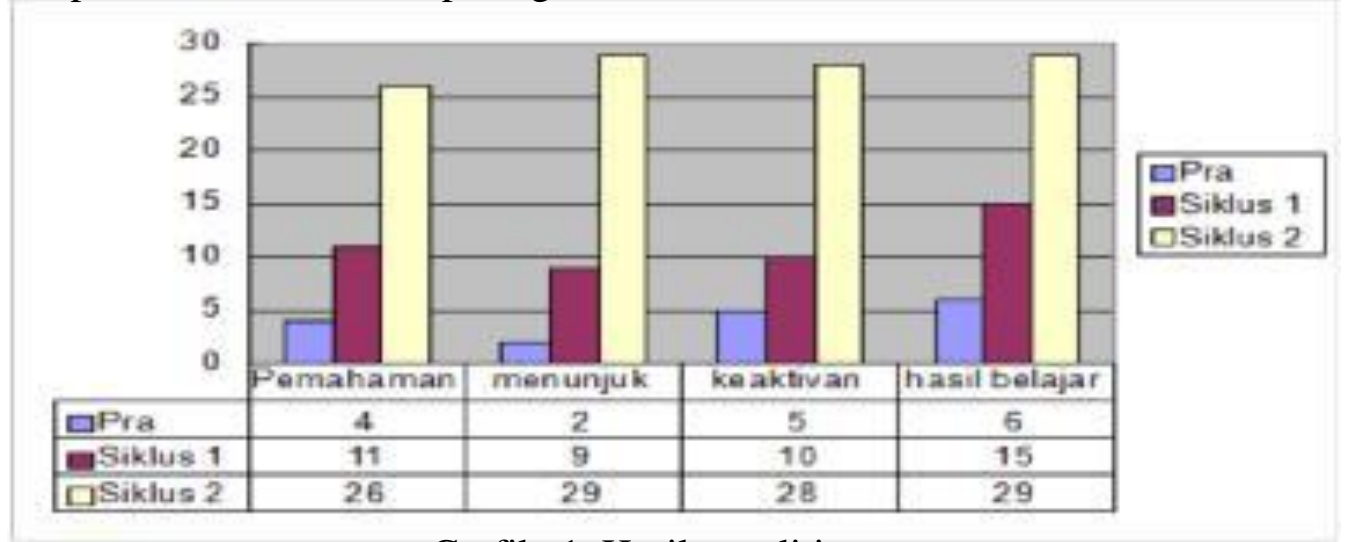

Grafik. 1. Hasil penelitian

Berdasarkan hasil penelitian ada grafik diatas, terlihat bahwa pembelajaran pada pelajaran IPS yang dilakukan guru dengan berceramah dan tidak menggunakan media pada tahap pra penelitian terlihat bahwa pemahaman materi siswa dalam pembelajaran hanya 4 siswa (13\%), sedangkan pada siklus 1 yang telah diterapkan pembelajaran dengan menggunakan media peta interaktif yakni 11 siswa (37\%), dan terjadi peningkatan yang signifikan di siklus 2 yakni 26 siswa (87\%). 
Hal ini membuktikan bahwa pembelajaran menggunakan media peta interaktif mampu meningkatkan mampu meningkatkan pemahaman siswa dalam mempelajari materi pelajaran terutama materi peta dunia dan Indonesia.

Pada kemampuan siswa dalam menunjukkan letak daerah atau lokasi pada saat pra penelitian hanya 2 siswa (7\%), sedangkan pada siklus 1 dan siklus 2 mengalami peningkatan yakni sebanyak 9 siswa (30\%) dan 29 siswa (97\%). Hal ini membuktikan bahwa siswa telah mampu memahami materi pelajaran terbukti siswa mampu menunjuk letak atau lokasi daerah di dunia dan di Indonesia yang ditunjuk atau diperintahkan oleh guru.

Pada keaktifan siswa dalam proses belajar juga mengalami peningkatan, yakni pada saat pra penelitian hanya 5 siswa $(17 \%)$, sedangkan pada saat menggunakan media peta interaktif terdapat 10 siswa (33\%) pada siklus 1 dan 28 siswa (93\%) pada siklus 2 yang berkomunikasi dan berinteraksi secara aktif dalam pembelajaran. Hal ini membuktikan bahwa terdapat komunikasi positif dalam pembelajaran sehingga siswa menjadi nyaman untuk berinteraksi dalam pembelajaran.

Dalam penelitian ini juga terlihat peningkatan hasil belajar siswa, yang pada awal pembelajaran (pra penelitian) hanya terdapat 6 siswa $(20 \%)$ yang mendapatkan nilai yang baik, setelah diterapkan pembelajaran dengan menggunakan media peta interaktif di siklus 1 dan siklus 2 mengalami peningkatan hsil belajar yakni sebanyak 15 siswa (50\%) dan 29 siswa (97\%) yang mendapatkan hasil yang memuaskan. Hal ini mengunjukkan bahwa pembelajaran dengan menggunakan peta interaktif dapat meningkatkan hasil belajar siswa.

\section{E. Kesimpulan dan Saran}

Berdasarkan hasil penelitian dapat disimpulkan bahwa terdapat peningkatan pembelajaran dengan menggunakan media peta interaktif, yakni : (1) pemahaman materi siswa dalam pembelajaran dari pra penelitian hanya 4 siswa yang mampu memahami materi pada bab peta, setelah diterapkan media peta interaktif terjadi peningkatan yakni pada siklus 1 terdapat 11 siswa dan siklus 2 terdapat 26 siswa.

(2). Kemampuan siswa dalam mampu menunjuk letak atau lokasi daerah di dunia dan di Indonesia yang ditunjuk atau diperintahkan oleh guru, dari pra penelitian hanya sebanyak 2 siswa, pada saat penerapan media peta interaktif terjadi peningkatan yang signifikan yakni pada siklus 1 sebanyak 9 siswa dan siklus 2 terdapat 29 siswa. (3) Keaktifan siswa dalam mengikuti pembelajaran, sebelumnya pada pra penelitian sebanyak 6 siswa, pada saat penerapan media peta interaktif mengalami peningkatan sebanyak 15 siswa pada siklus 1 dan siklus 2 sebanyak 29 siswa. (4) Hasil belajar siswa yang sebelum diterapkan media peta interaktif hanya 6 siswa yang mendapatkan nilai baik, mengalami peningkatan yang signifikan pada siklus 1 dan siklus 2 yakni terdapat 15 siswa yang mendapatkan nilai baik di siklus 1 dan 29 siswa yang mendapatkan nilai memuaskan di siklus 2. Hal ini menunjukkan bahwa pembelajaran menggunakan media peta interaktif dapat meningkatkan pemahaman dan hasil belajar siswa pada mata pelajaran IPS.

Berdasarkan kesimpulan penelitian tersebut, saran-saran yang disampaikan yakni: (1) Guru hendaknya menggunakan media pembelajaran yang mampu meningkatkan minat dan motivasi belajar siswa dalam pembelajaran IPS salah satu nya media peta interaktif, (2) Guru sebaiknya menggunakan metode pembelajaran yang mendukung proses belajar, (3) Guru hendaknya meningkatkan komunikasi, partisipasi dan interaksi pembelajaran terutama menggunakan media peta interaktif. 
78 | Premiere Educandum, Volume 4 Nomor 1, Juni 2014, 65-78

\section{DAFTAR PUSTAKA}

Ahmad Subari. (2005). Strategi Belajar Mengajar Micro Teaching. Jakarta : Quantum Teaching

Alex Moore. (2000). Teaching and Learning Pedagogy, Curriculum, and Culture. London : Routledge Falmer

Aminuddin Rasyad. (2003). Teori Belajar Dan Pembelajaran. Jakarta : UHAMKA PRESS dan Yayasan PEP-EX 8

Anissatul Mufarokah. (2009). Strategi Belajar Mengajar. Yogyakarta : PT Teras

Asep Jihad dan Abdul Haris. (2008). Evaluasi Pembelajaran. Yogyakarta : Multipressindo

Baharudin dan Esa Nur Wahyuni. (2007). Teori Belajar dan Pembelajaran. Yogyakarta : Ar-Ruzz Media Group

Daniel Muijs dan David R. (2008). Effecting Teaching : Teori Dan Aplikasi. (terjemahan Helly Prajito\&Sri Mulyantini) Yogyakarta : Pustaka Pelajar. (Buku asli diterbitkan tahun 2008).

Hadari Nawawi. 1993. Metode penelitian Bidang Sosial. Yogyakarta :Universitas Gajahmada Yogyakarta

Hudojo. 2003. Media dalam pembelajaran. Jakarta : Pusat sumber belajar

Maya Kartika. 2012. Pengenalan dan Pembelajaran IPS SD. Madiun : FIP IKIP PGRI Madiun.

Maya Kartika. 2014. Pembelajaran IPS di Sekolah Dasar, sesuai kurikulum 2013. Madiun : FIP IKIP PGRI Madiun

Oemar H Malik. 1994. Media Pendidikan. Bandung ; Citra Aditya Bakti

Syaiful Bahri. (2005). Guru dan Anak Didik Dalam Interaksi Edukatif suatu pendekatan teoritis Psikologis. Jakarta : PT. Rineka Cipta

Subyantoro. (2009). Penelitian Tindakan Kelas. Semarang : CV. Widya Karya.

Suharsimi Arikunto, dkk. (2006). Penelitian Tindakan Kelas. Jakarta : Bumi Aksara

Saidiharjo. 2002. Pengembangan materi IPS Terpadu. Yogyakarta : Program Pasca Sarjana Universitas Negeri Yogyakarta

Sardiman. 1992. Interaksi dan Motivasi Belajar Mengajar. Bandung : Rajawali Press

Tim PPPG IPS. 2005. Materi Pembelajaran IPS Untuk SMP. Surabaya : Tim PPPG IPS

Udin S Winata. 2007. Teori Belajar dan Pembelajaran. Universitas Terbuka. 